\title{
РЕЦЕНЗIї
}

DOI https://doi.org/10.32837/pyuv.v0i1(30).553

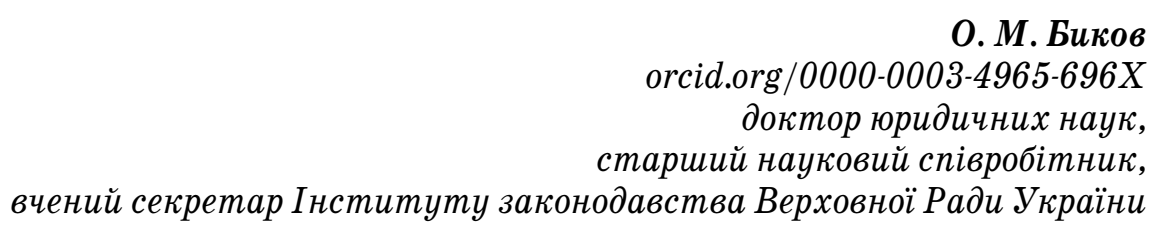

\section{РЕЦЕНЗІЯ НА МОНОГРАФІЮ І. О. КОСТИЦЬКОЇ «ЮРИДИЧНА ВІДПОВІДАЛЬНІСТЬ ПАРЛАМЕНТАРІЯ В СИСТЕМІ ВІДПОВІДАЛЬНОГО ПРЕДСТАВНИЦЬКОГО ПРАВЛІННЯ: КОНСТИТУЦІЙНО-ПРАВОВИЙ АНАЛІЗ»}

Проблематика посилення відповідальності публічної влади в сучасній Україні стоїть як ніколи гостро на порядку денному вітчизняного розвитку. Адже нині саме від відповідального ставлення до виконання своїх обов'язків кожного з посадовців багато в чому залежить успіх проголошених в Україні реформ у багатьох ділянках державного і суспільного життя. Водночас, попри певну традиційність для вітчизняної юриспруденції проблематики юридичної відповідальності, iï «заземлення» до сфери функціонування й діяльності публічної влади лише останнім часом стало елементом науково-правового дискурсу.

Важливо, що рецензована праця торкається такого важливого питання цієї проблематики, як питання юридичної відповідальності парламентаріїв. Звісно, не можна обійти увагою дисертаційні дослідження у цій сфері, що проводилися останніми роками в Україні (маємо на увазі насамперед роботи I.Є. Словської, В.В. Гецко, I.В. Рижук та інші), які заповнили чимало лакун у пізнанні цього конституційно-правового феномену. Проте специфічність та актуальність рецензованого дослідження полягає якраз у тому, що питання юридичної відповідальності народних депутатів в Україні розглядаються, по-перше, в широкому політико-правовому контексті, яким обрано систему відповідального представницького правління, а 3 іншого боку, через призму новітніх методологічних підходів, які є інноваційними для вітчизняної конституціоналістики. Деталізація уваги до юридичної відповідальності парламентарія виявляється прямо зумовленою необхідністю забезпечення функціональної дієздатності та інституційної спроможності парламенту як органу державної влади загалом.

Зважаючи на це, не можна не окреслити такі ключові змістовні новації монографії I.О. Костицької. Так, докладно доцільно зупинитися на доктринальних позиціях, авторки. Звернемо увагу на застосування значною мірою міждисциплінарного наукового підходу, що корелює зі складні- стю та багатоаспектністю досліджуваного політико-правового феномену. За авторського підходу парламентарій постає як особливий суб'єкт, наділений якостями, здатними втілювати його волю в конструювання правових смислів, уміщених у правових текстах, насамперед у законах. Відповідно, евристично цінним видається висновок, що «вже не парламент «конструює» (продукує) парламентарія, а навпаки, саме парламентарій виступає першоосновою для конструювання та розвитку парламенту і парламентаризму взагалі. Цілком правомірно І.О. Костицька вдається до конструювання своєрідного логічного ланцюжка «соціальна відповідальність парламентарія - ii різновиди і їх співвідношення - юридична відповідальність парламентарія як різновид соціальної відповідальності». Такий підхід теоретично та методологічно обгрунтований. Втім, він підкріплюється цікавими спостереженнями щодо своєрідної «нормативної відкритості» сфери юридичної відповідальності парламентарія: її зміст збагачується не лише шляхом саморозвитку інституту юридичної відповідальності парламентарія, але i за допомогою взаємовпливів і запозичень зі сфери інших різновидів соціальної відповідальності, зокрема політичної та корпоративної. Авторкою дослідження переконливо доведено методологічну хибність концепцій, які ототожнюють юридичну відповідальність парламентарія з політичною або з корпоративною. Акцентується увага на їх відносній самостійності та автономності анклавів відносин, що регулюються цими комплексами соціальних норм у сучасному суспільстві.

У монографії обгрунтовано, що юридична відповідальність парламентарія - це різновид соціальної відповідальності парламентарія, яка виражається у відповідальному ставленні парламентаріїв до здійснення їх повноважень, зумовлюючи заходи сприяння (заохочення) (позитивний аспект) та, за наявності чітко визначених правових підстав, призводить до настання юридично

${ }^{1}$ Костицька І. О. Юридична відповідальність парламентарія в системі відповідального представницького правління: конституційно-правовий аналіз : монографія. Херсон : Видавничий дім «Гельветика», 2019. $443 \mathrm{c.}$ 
несприятливих наслідків (негативний аспект), у вигляді застосування до парламентаріїв-порушників спеціальних юридичних санкцій, що накладаються в особливому процесуальному порядку уповноваженими органами державної влади (самим парламентом або іншими інстанціями відповідальності відповідно до їх компетенції).

Доктринально значимим та теоретично обгрунтованим $є$ запропонований аналіз ключових факторів, що впливають на конституційну інституціалізацію юридичної відповідальності парламентаріїв, а також дослідження конституційно-правових моделей юридичної відповідальності парламентаріїв. Тут авторка застосовувала порівняльно-юридичний та структурний підходи, що дали змогу виявити доволі широку палітру чинників, які сприяють структуризації юридичної відповідальності парламентаріїв, осмислити реально існуюче розмаїття конституційних моделей такої відповідальності (на основі аналізу текстів багатьох зарубіжних конституцій), а також з'ясувати видове розмаїття юридичної відповідальності парламентаріїв. Особливо значимими, на наш погляд, є виокремлені I.О. Костицькою з врахуванням сучасних здобутків юридичної науки та практики конституційно-правові характеристики юридичної відповідальності парламентарія: 1) у вигляді прямої конституційної заборони притягнення парламентарія до юридичної відповідальності на певні діяння, що, відповідно, звужує обсяг юридичної відповідальності цієї особи; 2) у вигляді відсилки до законодавчого регулювання принципів притягнення депутатів парламентаріїв до юридичної відповідальності; 3) у вигляді фіксації юридичних (конституційних) випадків (підстав) притягнення парламентаріїв до юридичної відповідальності; 4) у вигляді фіксації певних конституційно окреслених (безпосередньо поіменованих) видів юридичної відповідальності парламентаріїв, зокрема конституційної, дисциплінарної, цивільної; 5) у вигляді встановлення певних позитивних юридичних (конституційно-правових) зобов'язань або заборон, адресованих безпосередньо парламентаріям; 6) у вигляді встановлення інстанцій юридичної відповідальності парламентаріїв (перед самим лише парламентом; перед парламентом та судом; перед парламентом, судом та політичною партією, від якої вони балотувалися на виборах); 7) у вигляді прямої конституційної заборони імперативного мандата, що виключає народ (виборчий корпус) як інстанцію відповідальності за правопорушення з боку парламентарія.

Як переконливо довела I.О. Костицька, обсяг юридичної відповідальності парламентарія в різних країнах є украй нерівномірним. Водночас він має тенденцію до змістовного розширення і збагачення, що, безумовно, слід ураховувати і в Україні в ході національного право- та державотворення. Звідси випливають запропоновані шляхи модернізацї юридичної відповідальності парламентарія в контексті конституиійної реформи в сучасній Україні. Тут називаються посилення юридичної відповідальності парламентаріїв у контексті ключової тенденції конституційно-правового розвитку в Україні та у світі, з'ясовуються провідні загальнотеоретичні та конституційно-правові підходи до модернізації юридичної відповідальності парламентарія в контексті конституційної реформи, а також розкриті основні особливості модернізації юридичної відповідальності парламентарія як напряму підвищення рівня відповідальності парламенту України. Насамперед приваблює змістовна «щільність» концептуальних положень, оснащених відповідними конституційно-правовими здобутками і прорахунками. Динаміці відповідного процесу вдосконалення інституту юридичної відповідальності парламентарія сприяє класифікація окремих етапів означеного процесу, синхронізована із конституційною реформою та конституційним процесом. Цілком виправданим 3 науково-методологічного боку є прагнення «вписати» проблему юридичної відповідальності парламентарія в контекст саме конституційної реформи. Разом з тим авторка переконливо доводить, що проблема такого реформування вже перестала поміщатися власне в межах конституційного тексту.

I.O. Костицька аналізує здобутки та прорахунки на шляху модернізації інституту юридичної відповідальності парламентаріїв, зокрема спосіб конституційної ліквідації інституту парламентського імунітету, що фактично незабаром був дезавуйований змінами до Кримінального процесуального кодексу України та Закону України «Про статус народного депутата України». Аналізуючи відповідні законодавчі новації, авторка всебічно та об'єктивно осмислює їх зміст та окреслює ймовірні наслідки їх застосування, що свідчить про обгрунтованість зроблених висновків.

Це далеко не вичерпний перелік позитивних моментів у цій монографічній роботі, які можуть вплинути на процеси вітчизняної законотворчості, а також сприяти змістовному розвитку української конституціоналістики.

Авторка доволі прискіпливо розглянула національне законодавство у сфері юридичної відповідальності парламентарія. Проте, заглибившись у зміст конкретних актів та їх положень, вона уникла класифікаційного підходу, успішно застосованого нею ж в інших частинах роботи, до законодавчого масиву, з виокремленням груп відповідних законодавчих актів. Але це зауваження жодним чином не ставлять під сумнів теоретичну та практичну цінність рецензованого дослідження, а навпаки, має дати додатковий імпульс для подальших плідних наукових дискусій у науці конституційного права. 